\title{
Report on Spermophagus niger Motschulsky, 1866 (Coleoptera: Chrysomelidae: Bruchinae: Amblycerini) infesting the seeds of roselle, Hibiscus sabdariffa L. (Malvaceae) during post-harvest storage in Burkina Faso
}

\author{
A. Sanon ${ }^{\text {a, }}{ }^{*}$, J.C. Koussoube a, M.N. Ba ${ }^{\text {b }}$, L.C. Dabire-Binso ${ }^{c}$, M. Sembène ${ }^{d}$ \\ a Laboratory of Fundamental and Applied Entomology, UFR/SVT, University Ouaga I, 06 P Box 9499, Ouagadougou 06, Burkina Faso \\ ${ }^{\mathrm{b}}$ International Crops Research Institute for the Semi-Arid Tropics, Niamey, Niger \\ c Laboratory of Agricultural Entomology, CREAF Kamboinsé, INERA-CNRST, 01 P Box 476, Ouagadougou 01, Burkina Faso \\ ${ }^{\mathrm{d}}$ Department of Animal Biology, Faculty of Science and Technology, University Cheik Anta Diop, P. Box 5005, Dakar, Senegal
}

\section{A R T I C L E I N F O}

\section{Article history:}

Received 10 March 2017

Accepted 5 April 2017

\section{Keywords:}

Hibiscus sabdariffa

Spermophagus niger

Insect morphology

Post-embryonic development

Post-harvest management

\begin{abstract}
A B S T R A C T
This paper reports the presence and characteristics of the bruchid Spermophagus niger Motschulsky as a major pest of roselle (Hibiscus sabdariffa L.) seeds during post-harvest storage in Burkina Faso. Samples of roselle seeds collected in farmers granaries at three locations in Burkina Faso at the beginning of crop storage were brought to the laboratory and held for 2 months. All seed samples were infested with varying levels of $S$. niger, though samples from Tougan and Dedougou were more highly infested than those from Ouagadougou. Infested seeds generally had only one insect emergence hole, with seed perforation rates ranging from $1.8 \%$ to $4 \%$. Insect rearing in the laboratory provided an opportunity for a clearer discrimination of sexual dimorphism and a better morphological description of the species. Males were smaller and weighed less than females. Post-embryonic development, which took place entirely within the seed, included four larval instars and one pupal stage; these stages are common in the subfamily Bruchinae. Our preliminary observations will enable a better understanding of this previously little-known insect pest. Furthermore, these results offer baseline data for further into appropriate postharvest management of roselle in West Africa.
\end{abstract}

(C) 2017 Elsevier Ltd. All rights reserved.

\section{Introduction}

In West Africa, roselle, Hibiscus sabdariffa L. (Malvaceae), is mainly cultivated in savanna and semi-arid areas (Schippers, 2000). Formerly grown over a small area, roselle is receiving increasing attention as a crop with potential for socio-economic impacts (Sanou et al., 2005). Roselle is increasingly being appreciated for its various uses, including the use of calyces to produce valuable food products such as liquors, jellies, beverages, and jams (Amin et al., 2008). Roselle calyces are therefore the object of trade between various African and European countries (McClintock and El Tahir, 2004; Egharevba and Law- Ogbomo, 2007), representing a notable source of income for roselle producers. In Burkina Faso, roselle leaves and calyces are also used to prepare local sauces. In

\footnotetext{
* Corresponding author

E-mail address: sanonant@yahoo.fr (A. Sanon).
}

addition, the seeds are subjected to solid-state fermentation to produce a meat substitute condiment that is consumed in Burkina Faso, where it is known as Bi-kalaga (Bengaly et al., 2006) and in many other West African countries as well (Atta et al., 2013). Roselle seeds are also a valuable food resource owing to their protein, calorie, and fat content as well as the substantial amount of fiber and valuable micronutrients (Akanbi et al., 2009). Roselle calyces are also rich in vitamin $C$, and contain nine times the amount in vitamin C as citrus (Amin et al., 2008). Calyces are infused to prepare a popular drink called Bissap that is consumed throughout West Africa.

Roselle plays an important role in household food economies in West Africa. However, production of roselle and post-harvest preservation of seeds are subjected to biotic and abiotic constraints. In Burkina Faso, several insect orders are causing damage to roselle crops (Sanou et al., 2005). Moreover, a bruchid species identified as Spermophagus niger Motschulsky 1866 has been 
described as infesting seeds in post-harvest storage (Amadou et al., 2016; Koussoube et al., 2016), and is responsible for major losses in storage. This paper describes for the first time the infestation of roselle seeds by this beetle species. Insect rearing under laboratory conditions enabled us to gain information on S. niger morphology, post-embryonic instars, seed infestation levels and damage to seeds.

\section{Materials and methods}

\subsection{Collecting samples of roselle seeds and determining the level of infestation by $S$. niger}

In December 2009, five batches of $500 \mathrm{~g}$ roselle seeds were collected from newly harvested crops from farmers production at each of the three following locations: Tougan (W $3^{\circ} 4^{\prime} 10^{\prime \prime} / \mathrm{N}$ $13^{\circ} 04^{\prime} 21^{\prime \prime}$ ), Dedougou (W $3^{\circ} 27^{\prime} 36^{\prime \prime} / \mathrm{N} 12^{\circ} 27^{\prime} 47^{\prime \prime}$ ) and around Ouagadougou (W $1^{\circ} 31^{\prime} 05^{\prime \prime} / \mathrm{N} 12^{\circ} 21^{\prime} 58^{\prime \prime}$ ). These regions are known as major producers of roselle in Burkina Faso. The seed batches were taken to the laboratory and immediately placed in Plexiglas boxes $(18 \times 11 \times 4 \mathrm{~cm})$ and monitored for 60 days. During this monitoring, insects that emerged from the seeds were collected from each seed batch and then counted. Insects were then divided, with fifty individuals placed into jars containing 70\% alcohol and carefully labeled. The other portion of the insects were introduced into breeding boxes $(10 \times 8 \times 3 \mathrm{~cm})$, each containing $50 \mathrm{~g}$ of roselle seeds and fifty individual insects. The breeding insects were maintained at $32 \pm 0.1{ }^{\circ} \mathrm{C}$ and $36 \% \pm 1 \% \mathrm{r}$. h. After 60 days of monitoring, the 500 g-seed batches from each location were examined again to determine their damage status. Then, onehundred seeds were randomly taken from each batch to count the perforated seeds.

\subsection{Morphological identification of S. niger adults}

\subsubsection{Sex identification}

All the collected insects proved to belong to the same species. After initial identification, the insect were thoroughly inspected under a binocular microscope to identify the most representative morphological traits. Using the insects that emerged in the rearing boxes, we first tried to detect any apparent sexual dimorphism between adults. The most critical morphological criteria were then identified. To confirm this initial identification, insects of each identified sex were placed for $24 \mathrm{~h}$ in Petri dishes, each containing ten roselle seeds that were free of any infestation. The insects were then removed from the boxes and individuals who laid eggs on the seeds were classified as females. The experiment was replicated 50 times to allow us to successfully distinguish males and females. After this, we were able to give precise and sex-specific morphological descriptions.

Twenty-five individuals of each sex were randomly selected from first-generation insects that emerged in rearing boxes. Size was measured from the head to the pygidium using a binocular microscope equipped with millimeter graph paper. Weight was determined using an OHAUS Analytical Standard microbalance.

\subsection{Monitoring post-embryonic developmental instars}

To determine post-embryonic development, we conducted an experiment in which we infested healthy roselle seeds with newly emerging S. niger mating pairs each day for 20 days. Every day, three pairs of insects were introduced into one of 10 separate Petri dishes, each containing $10 \mathrm{~g}$ roselle seeds, for $24 \mathrm{~h}$. Starting on the date of the first egg hatching in each series of infested seeds, five seeds were dissected every 2 days to observe any developmental instars that occurred until the emergence of adults. This method allowed us to identify the major post-embryonic developmental instars of $S$. niger. We took measurements (length and width) and made descriptions of the major developmental instars based on the most representative individuals of each instar. Ten individuals of each post-embryonic developmental instar were selected for these measurements.

\subsection{Data analysis}

The recorded quantitative data were first subjected to analysis of variance (ANOVA) using SAS software version 9.1 (SAS, 2003). When significant differences were observed, means were separated using Fisher's LSD test at the 5\% probability level.

\section{Results}

\subsection{Adult insect morphology}

The collected insects were morphologically identified as Spermophagus niger according to the general description provided by Borowiec (1991). The examined specimens were mainly dark brown in color and had a body covered with bristles that often formed distinct bands on the abdomen. The head, which faced downwards, appeared sharp, with 11 brown, thread-like antennal articles. The convex and clearly visible pronotum had sharp lateral edges and extended back from the head. Elytra, which were similar in males and females, were short with rounded posterior margins and never covered the pygidium. The legs were also dark brown, with strong tibia and femora in the hind legs. Sharp dorsolateral carinas were also present on hind tibia.

The distinction between male and female specimens was not obvious. Here, for the first time, we report reliable morphological criteria for distinguishing specimens by sex. First, the pygidium is curved in males but straight in females. Moreover, in the ventral view, the end of the pygidium is visible in the male but hardly noticeable in the female. Sexual dimorphism was also confirmed by body size measurements. Males tended to be significantly smaller and weighed less than females (Table 1).

\subsection{Characterization of insect damage}

All collected seed batches of roselle exhibited the emergence of S. niger individuals at varying levels of infestation and damage. The batches from Tougan and Dedougou were more infested than those from Ouagadougou (Table 2). Seed damage included the removal of internal reserves by larvae feeding during their development and perforation of seeds by adult insects once they were fully developed. Thus, $1.8 \%-4 \%$ of the seeds examined at the end of monitoring were perforated (Table 2). Infested seeds presented regular emergence holes and were covered with many eggs laid by newly emerging females. However, usually only one emerging hole was observed per seed.

Table 1

Mean $({ } \mathrm{SD}$ ) body size and weight of males and females $S$. niger emerging from roselle seeds. Min-Max represented minimal and maximal measurements.

\begin{tabular}{llllll}
\hline & \multicolumn{2}{l}{ Body Size $(\mathrm{mm})$} & & Weight $(\mathrm{mg})$ & \\
\cline { 2 - 3 } \cline { 5 - 6 } \cline { 5 - 6 } & Mean $( \pm$ SD $)$ & Min - Max & & Mean $( \pm$ SD $)$ & Min - Max \\
\hline Male $(\mathrm{n}=25)$ & $3.54 \pm 0.16$ & $3.4-3.8$ & & $5.16 \pm 0.51$ & $4.2-5.9$ \\
Female $(\mathrm{n}=25)$ & $3.76 \pm 0.18$ & $3.5-4.0$ & & $5.57 \pm 0.58$ & $4.0-6.3$ \\
ANOVA & 20.37 & & & 6.65 & \\
$P$ & $<0.0001$ & & 0.0130 & \\
\hline
\end{tabular}


Table 2

Infestation levels of roselle seeds by $S$. niger depending on the origin of the seeds at the beginning of storage in three locations in Burkina Faso. ( $\mathrm{n}=5$ replicates).

\begin{tabular}{llllll}
\hline Locations & \multicolumn{2}{l}{ S. niger numbers/500 $\mathrm{g}$} & & \multicolumn{2}{l}{$\begin{array}{l}\text { \% Perforated seeds/100 } \\
\text { seeds }\end{array}$} \\
\cline { 2 - 3 } \cline { 6 - 7 } & Mean $( \pm \mathrm{SD})$ & IC 95\% & & Mean $( \pm$ SD $)$ & IC 95\% \\
\hline Ouagadougou & $32.4 \pm 7.3 \mathrm{~b}$ & $24.1-40.7$ & & $1.8 \pm 1.1 \mathrm{~b}$ & $0.5-3.1$ \\
Tougan & $64.6 \pm 7.2 \mathrm{a}$ & $56.2-72.9$ & & $4.0 \pm 1.6 \mathrm{a}$ & $2.7-5.3$ \\
Dedougou & $56.0 \pm 10.7 \mathrm{a}$ & $47.6-64.3$ & & $3.0 \pm 1.2 \mathrm{ab}$ & $1.7-4.3$ \\
\hline
\end{tabular}

Means within a column followed by the same alphabetic letter did not differ according to the Fisher LSD test at the probability of $5 \%$.

\subsection{Immature stages during post-embryonic development}

The immature stages of $S$. niger include the egg stage, four larval stages and a pupal stage. The translucent eggs were oblong in shape and generally adhered to the wall of the seed. Egg size was approximately $0.48 \pm 0.04 \mathrm{~mm}$ long and $0.2 \pm 0.02 \mathrm{~mm}$ wide (Table 3). The first instar larva, characteristic of the chrysomelian type, was white and approximately $0.79 \pm 0.07 \mathrm{~mm}$ long (Table 3 ). The larva underwent gradual growth until the third instar without changing shape. At the third instar stage, larval growth appeared to be important and the larvae were an average of $1.82 \pm 0.35 \mathrm{~mm}$ long. Fourth instar larvae were white, and slightly morphologically different from the previous stages. Larvae of this stage appeared to be less curved than in the previous stages and were $2.93 \pm 0.5 \mathrm{~mm}$ long on average. Pupae were initially white and not curved $(3.88 \pm 0.19 \mathrm{~mm}$ long) and they gradually become sclerotized and brownish in color before transforming into adults. The overall development duration was on average $34.0 \pm 0.7$ days in our experimental conditions.

\section{Discussion}

This study confirms that Spermophagus niger, a little-known bruchine species is a pest of roselle seeds during post-harvest storage in Burkina Faso. Genetic characterization of individuals collected from roselle seeds in Burkina Faso (Koussoube et al., 2016) previously confirmed the identification of this insect species. Thus it is clear that the insect pest of roselle seeds is S. niger, rather than Zabrotes subfasciatus, another beetle species with morphological similarities that is easily confused with $S$. niger. The genus Spermophagus was described by Schoenherr and revisited by several authors including Borowiec $(1987,1991)$. Spermophagus species are widespread in the Old World, especially in the Afrotropical, Indomalaya and Palearctic regions (Delobel, 2008; Delobel and Anton, 2011; Kergoat et al., 2015). This genus includes species belonging to the subfamily Bruchinae. However, little is known about S. niger and its host plants in the West African region. Furthermore, the first detailed description of $S$. niger by Borowiec (1991) did not allow easy discernment of sex. Our study showed that, as in other bruchid species, sexual dimorphism exists in S. niger and, furthermore, by observing the shape of pygidium, we can more easily distinguish males and females. This is important because it will allow us to conduct more detailed studies to better understand the bio-ecology of this species.

Most Bruchinae species are mostly associated with leguminous seeds, particularly those of plants in the family Fabaceae (Johnson and Romero, 2004). However, the genus Spermophagus specializes on two families of non-leguminous host plants: Convolvulacae and Malvaceae (Borowiec, 1987; Kergoat et al., 2015). It is therefore not surprising that we find $S$. niger on roselle, which is a member of the Malvaceae family. To our knowledge, this is also the only host plant of $S$. niger that has been reported in West Africa. It would be interesting to investigate in other cultivated Malvaceae to determine the host range of this species and its pest status in West Africa. In fact most of bruchine species have limited host plant range and are usually associated with host plant species, which belong to one genus or botanical tribe (Delobel and Delobel, 2006; Kergoat et al., 2015).

In the current study, S. niger was observed in samples from three locations in Burkina Faso, which suggests that all the roselle growing areas of the country may be colonized by the insect. The differences in observed infestation levels could be the result of the larger growing area of roselle in Dedougou and Tougan where infestation rates were higher. Or, the difference may be have derived from better adaptation of the insect in these localities. Further studies including samples from all the areas of roselle production are needed to confirm these suggestions and to map the distribution of S. niger in Burkina Faso.

Although the levels of infestations were generally low $(<5 \%)$, seed damage was similar to those caused by other Bruchine species as the cowpea weevil Callosobruchus maculatus Fab. (Ouédraogo, 1991). Furthermore, the lack of effective control methods against S. niger will necessarily lead to high crop losses. Triple-bagging using PICS $^{\odot}$ bags has been reported to be effective for roselle seed preservation (Amadou et al., 2016). To our knowledge, S. niger

Table 3

Size (mean $\pm \mathrm{SD}$ ) variations in eggs and the main post-embryonic developmental stages of $S$. niger.

Length $(\mathrm{mm})$

\begin{tabular}{|c|c|}
\hline \multicolumn{2}{|c|}{$\begin{array}{l}\text { Immature st } \\
(\mathrm{n}=10)\end{array}$} \\
\hline & Egg \\
\hline & L1 \\
\hline 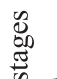 & L2 \\
\hline ᄅ & L3 \\
\hline$\widetilde{\Xi}$ & \\
\hline
\end{tabular}

Pupa
Mean $( \pm \mathrm{SD}) \quad$ Min $-\max$

$0.48 \pm 0.04$

$0,79 \pm 0,07$

$1,03 \pm 0,14$

$1,82 \pm 0,35$

$2,93 \pm 0,50$

$3,88 \pm 0,19$
$0.44-0.59$

$0,6-0,9$

$0,8-1,3$

$1,2-2,9$

$1,9-4,2$

$3,3-4,2$
Width (mm)

Mean $( \pm$ SD) $\quad$ Min $-\max$

$0.20 \pm 0.02$

$0.18-0.22$

$0.32 \pm 0.09$

$0.2-0.5$

$0.81 \pm 0.17$

$0.6-1.2$

$1.30 \pm 0.20$

$0.9-1.6$

$1.49 \pm 0.22$

$1.2-1.8$

$1.69 \pm 0.16$

$1.5-2.0$ 
has been reported on roselle seeds only in Burkina Faso (the current study; Koussoube et al., 2016) and Niger (Amadou et al., 2016), although Amadou et al. (2016) failed to precisely identify their specimens at the species level. Because roselle is grown in several other countries in West Africa (Schippers, 2000), it is likely that the same insect species is also present in those countries. Since the roselle cropping is increasing (Sanou et al., 2005; Egharevba and Law- Ogbomo, 2007), it will be important to pay more attention to this insect pest to better understand its impact in West Africa.

The biology of $S$. niger is similar to that of other bruchine species associated with leguminous seeds. This insect develops fully in the roselle seeds through four larval stages and a pupal stage. Based on the observation that there was only one emergence hole per seed, we suggest that each roselle seed allows the development of a single individual. It will be necessary to further confirm this result, but the morphology of the seed may explain this limitation. Because roselle seeds are usually flat, they probably contain limited food reserves to support the development of more than one larva. Previous studies have demonstrated that seed size can influence the size of developing larvae, competitive interactions, and the number of individuals produced from the same host (Toquenaga, 1993; Messina, 2004). The practical applications for these results on the dynamics of infestation of roselle stocks and their destructive capacity remain to be determined.

\section{Acknowledgements}

Technicians from the national research institute (INERA) and Agriculture department in Burkina Faso are thanked for providing with roselle seed samples. This research did not receive any specific grant from funding agencies in the public, commercial, or not-forprofit sectors.

\section{References}

Akanbi, W.B., Olaniyan, A.B., Togun, A.O., Hupeju, A.E.O., Alaniran, O.A., 2009. The effects of organic fertilizer on growth, calyx yield and quality of Roselle (Hibiscus sabdariffa L.). Am.-Eurasian J. Sustain. Agric. 3, 652-657.

Amadou, L., Baoua, I.B., Baributsa, D., Williams, S.B., Murdoch, L.L., 2016. Triple bag hermetic technology for controlling a bruchid (Spermophagus sp.) (Coleoptera, Chrysomelidae) in stored Hibiscus sabdariffa grain. J. Stored Prod. Res. 69, $22-25$.

Amin, I., Hainida, E.K.I., Halimatul, S.M.N., 2008. Roselle (Hibiscus sabdariffa L.) seeds- Nutritional composition, protein quality and health benefits. Foods 2
$1-16$.

Atta, S., Sarr, B., Diallo, A.B., Bakasso, Y., Lona, I., Saadou, M., 2013. Nutrients composition of calyces and seeds of three Roselle (Hibiscus sabdariffa L.) ecotypes from Niger. Afr. J. Biotechnol. 12, 4174-4178.

Bengaly, M., Béré, A., Traoré, A., 2006. The chemical composition of bikalga, a traditional fermented roselle (Hibiscus sabdariffa L.) seeds condiment. Part II: evaluation of mineral, total polyphenols and phytic acid content, predicting the iron bioavailability. EJFPC 1, 7-11.

Borowiec, L., 1987. The genera of seed beetles (Coleoptera, Bruchidae). Pol. Pismo Entomol. 57, 3-207.

Borowiec, L., 1991. Revision of the genus Spermophagus Schoenherr (Coleoptera, Bruchidae, Amblycerinae). Genus - Int. J. Invertebr. Taxonomy Suppl. 3-64 (Wroclaw).

Delobel, A., 2008. The genus Spermophagus in Vietnam: biological data and description of three new species (Coleoptera: Chrysomelidae: Bruchinae: Amblycerini). Genus - Int. J. Invertebr. Taxonomy 19, 201-211.

Delobel, B., Delobel, A., 2006. Dietary specialization in European species groups of seed beetles (Coleoptera: Bruchidae: Bruchinae). Oecologia 149, 428-443.

Delobel, A., Anton, K.W., 2011. New data on Spermophagus from Vietnam, with the description of a new species (Coleoptera: Chrysomelidae: Bruchinae: Amblycerini). Genus - Int. J. Invertebr. Taxonomy 22, 261-270.

Egharevba, R.K.A., Law-Ogbomo, K.E., 2007. Comparative effects of two nitrogen sources on the growth and the yield of Roselle (Hibiscus sabdariffa) in rainforest region: a case study of Benin-city, Edo state. Niger. J. Agron. 6, 142-146.

Johnson, C.D., Romero, J., 2004. A review of evolution of oviposition guilds in the Bruchidae (Coleoptera). Rev. Brasilian Entomology 48, 401-408.

Kergoat, G.J., Le Ru, B.P., Sadeghi, S.E., Tuda, M., Reid, C.A.C.M., Gyorgy, Z., Genson, G. Ribeiro-Costa, G.S., Delobel, A., 2015. Evolution of Spermophagus seed beetles (Coleoptera, Bruchinae, Amblycerini) indicates both synchronous and delayed colonizations of host plants. Mol. Phylogenetics Evol. 89, 91-103.

Koussoube, J.C., Mbaye, F., Dia, C.A.K.M., Sembène, M., Sanon, A., 2016. Genetic characterization of Spermophagus Niger (Coleoptera: Chrysomelidae: Bruchinae: Amblycerini) pest associated to seeds of sorrel (Hibiscus sabdariffa L.) in Burkina Faso, South Asian J. Exp. Biol, 6, 7-14.

McClintock, N.C., El Tahir, J.M., 2004. Prota 2; Legumes Record Display. Available on: database.prota.org/PROTAhtml/Hibiscussabdariffa_En.htm.

Messina, J.F., 2004. Predictable modification of body size and competitive ability following a host shift by a seed beetle. Evolution 58, 2788-2797.

Ouédraogo, A.P., 1991. Le déterminisme du polymorphisme imaginal chez Callosobruchus maculatus Fab. (Coléoptère: Bruchidae). Son importance sur la biologie des populations de ce Bruchidae. Thèse de Doctorat d'Etat. Université François Rabelais, Tours, p. 113.

Sanou, J., Ouédraogo, L., Sanfo, D., Neya, B., Somda, L., Paré, P., 2005. Rapport d'activités de recherche sur le développement des fibres végétales au Burkina Faso. Campagne 2004, Farako-Bâ, CRREA-Ouest, station de Farako-Bâ. BoboDioulasso, Burkina Faso, p. 45.

SAS, 2003. SAS Version 9.1 for Windows. SAS Institute, Cary, North Carolina, USA.

Schippers, R.R., 2000. African Indigenous Vegetable: an Overview of the Cultivated Species. Natural Resources Institute/ACP-EU. Technical Center for Agricultural and Rural Cooperation, Chatam, U.K, 1-124.

Toquenaga, Y, 1993. Contest and scramble competitions in Callosobruchus maculatus (Coleoptera: Bruchidae) II. Larval competition and interference mechanisms. Res. Popul. Ecol. 35, 57-68. 